\title{
Synthesis, rearrangement and solvolysis of propargylic and allylic trifluoromethanesulfinates
}

\author{
Samuel Braverman*, Tatiana Pechenick, and Yossi Zafrani \\ Department of Chemistry, Bar-Ilan University, Ramat-Gan 52900, Israel \\ E-mail: bravers@mail.biu.ac.il
}

Dedicated to Professor Binne Zwanenburg on his $70^{\text {th }}$ birthday

(received 12 Oct 03; accepted 26 Nov 03; published on the web 28 Nov 03)

\begin{abstract}
The synthesis and reactivity of propargylic and allylic trifluoromethanesulfinates under various conditions has been investigated. Propargylic esters readily undergo [2,3]-sigmatropic rearrangement to the corresponding allenyl trifluoromethyl sulfones, even under solvolytic conditions. An unusually facile nucleophilic addition of the solvent to the allenyl sulfone under the latter conditions has also been observed. On the other hand, the reactivity of allylic esters strongly depends on substitution. Thus, while cinnamyl triflinate reacts by an ionic mechanism, the corresponding $\alpha$-methylallyl ester reacts by a concerted pathway.
\end{abstract}

Keywords: Alkenes, acetylenes, allenes, trifluoromethanesulfinates, trifloromethyl sulfones, $[2,3]$-sigmatropic rearrangements

\section{Introduction}

The [2,3]-sigmatropic rearrangement of allylic arenesulfinates to allylic aryl sulfones (eq. 2) discovered by us over three decades ago, ${ }^{1 \mathrm{a}}$ was subsequently used as a model for the analogous rearrangement of allylic sulfenates to sulfoxides (eq. 1), ${ }^{1 \mathrm{~b}}$ as well as for the related rearrangements of propargylic sulfenates ${ }^{1 \mathrm{c}}$ and sulfinates ${ }^{1 \mathrm{~d}}$ to allenic sulfoxides and sulfones, respectively (eqs. 3,4). Detailed mechanistic studies have shown that all four rearrangements proceed by a concerted mechanism. Due to their high stereoselectivity and efficiency, these rearrangements have found extensive application in organic synthesis since their publication. ${ }^{2}$ The reversible allylic sulfenate-sulfoxide interconversion, also known as the Mislow-BravermanEvans rearrangement, ${ }^{3}$ has been of particular interest in this respect. ${ }^{2 b, d}$ 

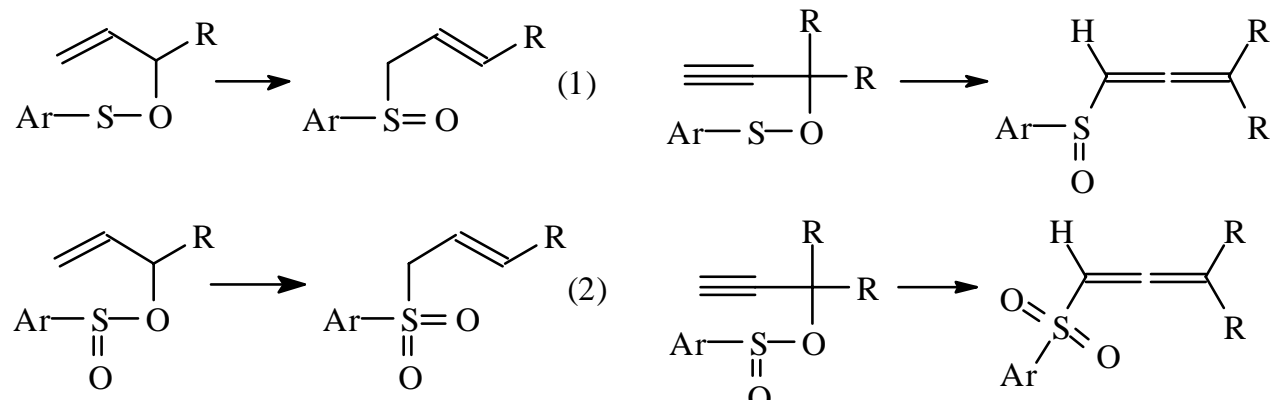<smiles></smiles>

More recently, we have shown that benzylic trichloro ${ }^{4 a}$ and trifluoromethanesulfinates ${ }^{4 b}$ exhibit some unique features. Thus, in contrast to benzyl arenesulfinates which undergo solvolysis with exclusive S-O bond fission, these esters undergo solvolysis with exclusive C-O bond fission, and with a rate enhancement by a factor of 6-powers of ten, comparable with benzyl tosylates. Similarly, unlike benzyl arenesulfinates, ${ }^{4 c}$ these esters undergo a facile rearrangement to sulfones on heating in polar nonhydroxylic solvents. The unusually high reactivity of these trihalomethanesulfinates has been explained by the enhanced leaving group ability of the corresponding anion, which in turn can be explained by the considerable difference in $\mathrm{pKa}$ values of $\mathrm{ArSO}_{2} \mathrm{H}(\mathrm{pKa}=2.7)$ and $\mathrm{CF}_{3} \mathrm{SO}_{2} \mathrm{H}(\mathrm{pKa}=-0.6) .{ }^{4 \mathrm{~d}}$ Prompted by these results, we became interested in the behavior of propargylic trifluoromethanesulfinates (triflinates) in order to test the effect of the $\mathrm{CF}_{3}$ group on the mechanism of rearrangement. In addition, we were interested in the preparation of some allenic trifluoromethyl sulfones (triflones) which might exhibit high reactivity in nucleophilic addition. The latter is of considerable interest with regard to recent studies on the DNA-cleaving ability of various enediyne models. ${ }^{5}$

\section{Results and Discussion}

\section{(a) Propargylic triflinates}

In the past, we have synthesized benzyl trichloro- ${ }^{4 a}$ and trifluoromethanesulfinates ${ }^{4 b}$ by oxidation of the appropriate sulfenate esters with m-CPBA in methylene chloride at $0{ }^{0} \mathrm{C}$. The sulfenate esters are also readily available by reaction of the appropriate alcohol with commercially available trihalomethanesulfenyl chlorides. However, this method was not applicable for the preparation of propargylic and allylic triflinates due to their potential [2,3]-sigmatropic rearrangement to allenic and allylic sulfoxides, respectively. ${ }^{1 \mathrm{a}, \mathrm{d}}$ Therefore, we decided to use another method which was reported by Klunder and Sharpless ${ }^{6}$ for the preparation of various menthyl sulfinates. This method involves the reaction of alcohol with $\mathrm{CF}_{3} \mathrm{~S}(\mathrm{O}) \mathrm{Cl}$ generated in situ by reduction of the corresponding sulfonyl chloride with trimethyl phosphite (eq. 5). However, in our hands, this method was only successful after several modifications, ${ }^{7}$ such as lowering the temperature to $-20{ }^{0} \mathrm{C}$, shortening the time to minimum, and reducing the amount of $(\mathrm{MeO})_{3} \mathrm{P}$ from two to one equivalent. Thus, several different propargylic triflinates have been prepared in good yields (eq. 5). 
<smiles>[R]C#CC([R])([R])O</smiles>

1a; $\mathrm{R}^{1}=\mathrm{R}^{2}=\mathrm{H}, \mathrm{R}^{3}=\mathrm{Me}$,

b; $\mathrm{R}^{1}=\mathrm{H}, \mathrm{R}^{2}=\mathrm{R}^{3}=\mathrm{Me}$,

c; $\mathrm{R}^{1}=\mathrm{H}, \mathrm{R}^{2}=\mathrm{Me}, \mathrm{R}^{3}=\mathrm{Et}$,

d; $\mathrm{R}^{1}=\mathrm{H}, \mathrm{R}^{2}=\mathrm{Me}, \mathrm{R}^{3}=\mathrm{Ph}$.

Interestingly, and unlike the other triflinates prepared, $\alpha$-methyl- $\alpha$-phenylpropargyl triflinate 2d could not be isolated because of spontaneous rearrangement to $\gamma$-methyl- $\gamma$-phenylallenyl triflone, indicating a full acetylene-allene isomerization, as expected from a concerted [2,3]sigmatropic shift (eq. 4).

To study the reactivity of the new triflinates, we first examined their behavior under nonsolvolytic conditions. We have thus found that similar to the previous case, $\alpha, \alpha$-dimethyland $\alpha$-ethyl- $\alpha$-methylpropargyl triflinates (2b and $2 \mathbf{c}$ respectively) also readily and exclusively undergo rearrangement to the corresponding $\gamma, \gamma$-dialkylallenyl triflones (3b,c eq. 6). ${ }^{7}$<smiles>[R]C#CC([R])([R])OS(C)(=O)=O</smiles>

2a; $\mathrm{R}^{1}=\mathrm{R}^{2}=\mathrm{H}, \mathrm{R}^{3}=\mathrm{Me}$,

b; $\mathrm{R}^{1}=\mathrm{H}, \mathrm{R}^{2}=\mathrm{R}^{3}=\mathrm{Me}$, c; $\mathrm{R}^{1}=\mathrm{H}, \mathrm{R}^{2}=\mathrm{Me}, \mathrm{R}^{3}=\mathrm{Et}$.
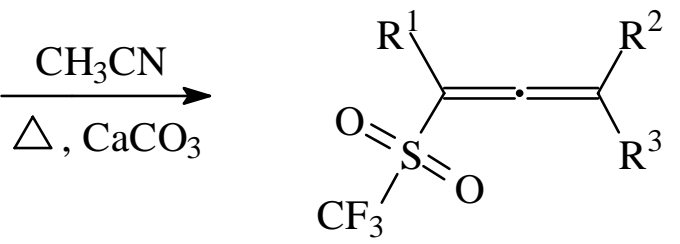

3a-c

Interestingly, the rate of rearrangement of $\alpha, \alpha$-dimethylpropargyl triflinate in acetonitrile at $40{ }^{0} \mathrm{C}\left(\mathrm{k}=2 \times 10^{-5} \mathrm{sec}^{-1}\right)$ is twice as rapid as in chloroform $\left(\mathrm{k}=9 \times 10^{-6} \mathrm{sec}^{-1}\right)$. This result is similar to the one found for propargyl arenesulfinates. ${ }^{1 \mathrm{~d}}$ The low sensitivity to solvent ionizing power may be used as evidence for a concerted [2,3]-sigmatropic shift for the rearrangement. Similarly, the exclusive rearrangement of these esters to allenic products may also be used as evidence for such a mechanism. Interestingly, a comparison of the reactivity of $\alpha, \alpha$-dimethylpropargyl triflinate $\mathbf{2 b}$ and benzenesulfinate ${ }^{1 \mathrm{~d}}$ shows that the former is faster by a factor of ca. 5 . In fact, the decreased nucleophilicity of the sulfur atom in the triflinate might be expected to decrease the rate of a concerted rearrangement. However, since precisely the same shift also involves cleavage of a better leaving group in the transition state, this may compensate in the opposite direction. For comparison, substitution of the aryl group by a trichloromethyl group in the case of benzylic sulfinates results in a much higher rate enhancement, for both solvolysis and rearrangement to sulfone, which proceed by an ionic mechanism. ${ }^{4 a-c}$ 
A different behavior has been observed with the secondary $\alpha$-methylpropargyl triflinate $2 \mathbf{2 a}$. We have found that heating this ester in acetonitrile for 2 months at $60{ }^{\circ} \mathrm{C}$ over $\mathrm{CaCO}_{3}$ afforded a mixture of $\gamma$-methylallenyl and $\gamma$-methylpropargyl triflones in the ratio of 1:2. In contrast to this result, in the absence of the base, only the first product (3a) was obtained. The conversion of the latter to the other isomer can be explained by a base catalyzed prototropic shift, as shown in eq. 7.

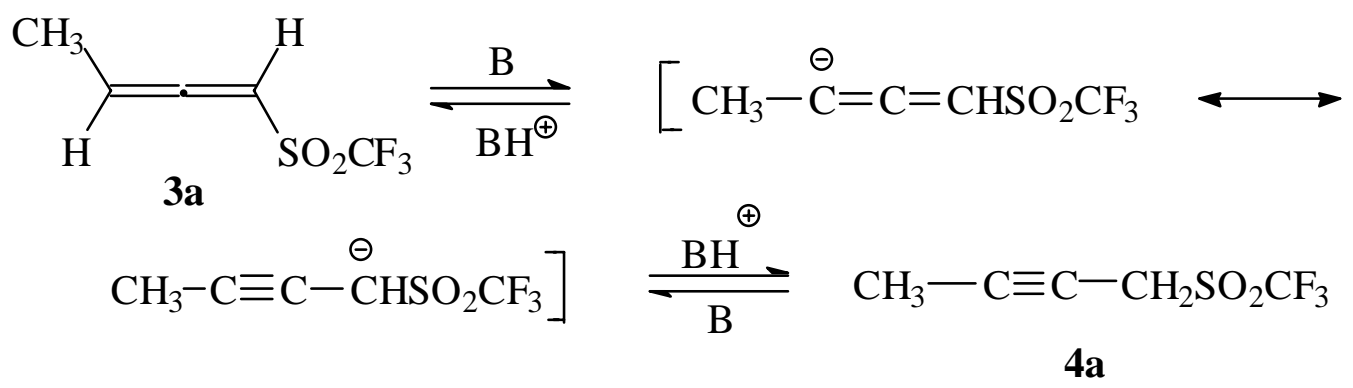

This result is quite similar to the one observed previously with $\gamma$-methylallenyl phenyl sulfone in the presence of 2,6-lutidine, but not of $\mathrm{CaCO}_{3}$, indicating that the latter is not basic enough to deprotonate the allenyl phenyl sulfone. This observation may reflect the relative acidities of the two allenyl sulfones. Our observations are also consistent with the thermodynamic data, which indicate that a nonterminal acetylene is more stable than an isomeric nonterminal allene by $1.0 \mathrm{Kcal} / \mathrm{mole}^{1 \mathrm{~d}}$ The formation of $\gamma$-methylallenyl triflone as the sole product is consistent with the results obtained with the $\alpha, \alpha$-disubstituted propargylic triflinates described above.

Prompted by these results, we decided to investigate the behavior of the new esters under solvolytic conditions. Surprisingly, heating of $\mathbf{2 b}$ for $5 \mathrm{~h}$ at $60{ }^{0} \mathrm{C}$ in ethanol yielded $\beta$-ethoxy- $\gamma, \gamma-$ dimethylallyl triflone (5b, $65 \%$ yield, eq. 8). Similarly, reaction of $\mathbf{2 c}$ under the same conditions yielded $\beta$-ethoxy- $\gamma$-ethyl- $\gamma$-methylallyl triflone $5 \mathbf{c}$. The latter product was obtained as a mixture of two diasterioisomers, $Z$ and $E$ in the ratio of 1:1.1. The formation of these unexpected products can be explained by rearrangement of the propargylic triflinates to allenic triflones and subsequent nucleophilic addition of ethanol to the allenic $\beta$-carbon.

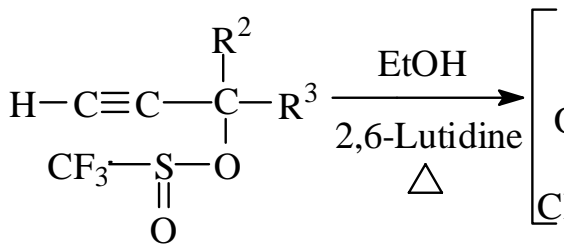

2b; $\mathrm{R}^{2}=\mathrm{R}^{3}=\mathrm{Me}$, c; $\mathrm{R}^{2}=\mathrm{Me}, \mathrm{R}^{3}=\mathrm{Et}$.

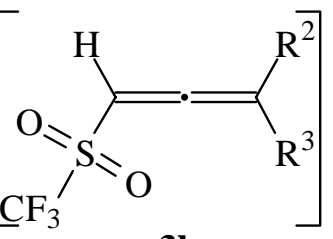

3b,c

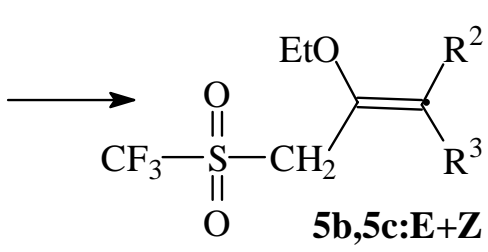

This explanation is supported by the observation that when $\gamma$-methyl- $\gamma$-phenylallenyl triflone 3d was tested under the same conditions, the corresponding product of nucleophilic addition 5d was obtained, again as a mixture of $Z$ and $E$ diasterioisomers in the ratio of 1:1.5 (eq. 9). 


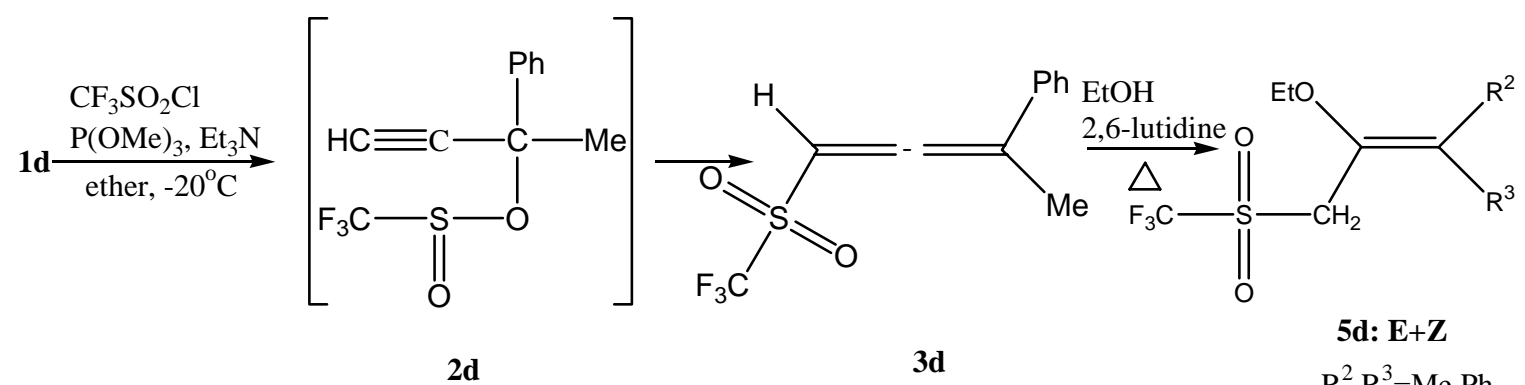

The data presented above for propargylic triflinates are similar to those reported on the rearrangement of propargylic arenesulfinates. ${ }^{\text {ld }}$ These esters rearranged to the corresponding allenic aryl sulfones almost exclusively even under solvolytic conditions. The unusual nucleophilic addition of ethanol to allenyl triflones can be explained by a higher electrophilicity of the allenic group in triflones comparable to aryl sulfones. It is interesting to note that the addition of alcohols to allenyl aryl sulfones occurs only under more drastic conditions such as in the presence of $\mathrm{NaH}^{8}{ }^{8}$ Our results are of particular significance with regard to the recent interest in the DNA - cleaving ability of allenyl sulfones. ${ }^{5}$

In conclusion, and in light of the evidence presented above, we suggest that the rearrangement of propargylic triflinates proceeds by a concerted [2,3]-sigmatropic mechanism, even under solvolytic conditions.

\section{(b) Allylic triflinates}

Prompted by the results described above, we decided to investigate the behavior of the allylic triflinates as well. These compounds were briefly investigated by Hendrickson and Skipper, only under nonsolvolytic conditions. ${ }^{9}$ These workers reported that the rearrangement of both $\alpha$ - and $\gamma$ propylallyl triflinates on heating in acetonitrile yields the same sulfone, $\gamma$-propylallyl triflone. The lack of allylic rearrangement in the latter case may be explained by an ionization mechanism, which is facilitated by the better leaving-group ability of the triflinate anion, as compared with the arenesulfinate anion. Alternatively, the ionization mechanism may be a consequence of the unbuffered conditions in which these reactions were performed. ${ }^{9}$

Thus, several different allylic triflinates have been prepared in good yields (eq. 10) using the same method as for preparation of propargylic derivatives.

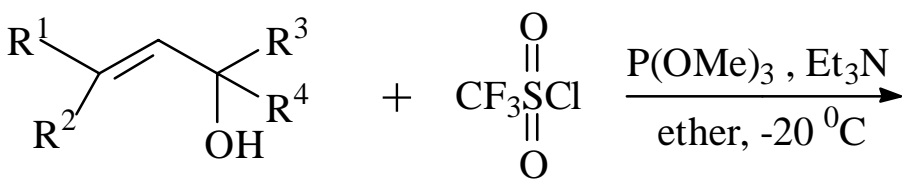

6a; $\mathrm{R}^{1}=\mathrm{Ph}, \mathrm{R}^{2}=\mathrm{R}^{3}=\mathrm{R}^{4}=\mathrm{H}$, b; $\mathrm{R}^{1}=\mathrm{R}^{2}=\mathrm{R}^{3}=\mathrm{H}, \mathrm{R}^{4}=\mathrm{Me}$, c; $\mathrm{R}^{1}=\mathrm{R}^{2}=\mathrm{H}, \mathrm{R}^{3}=\mathrm{R}^{4}=\mathrm{Me}$.<smiles>[R]C([R])=CC([R])([R])OS(=O)(=O)C([R])([R])[R]</smiles>

7a-c 
Unlike the propargylic derivatives, the allylic esters exhibited different behavior, and therefore we will discuss each one separately. We first tested the reactivity of cinnamyl triflinate 7a under nonsolvolytic conditions. In sharp contrast to allylic arenesulfinates which undergo rearrangement to sulfones with complete inversion of the allyl group (eq. 2), ${ }^{1 \mathrm{a}}$ the rearrangement of cinnamyl triflinate led to a mixture of three triflone products $\mathbf{8 ,} \mathbf{9}$ and $\mathbf{1 0}$ in the ratio of 1:2.4:2.9 (eq. 11). These results are suggestive of an ionization mechanism. Additional evidence for the ionic mechanism is based on kinetic data. For example, while rearrangement of cinnamyl 2,6-dimethylbenzenesulfinates to the corresponding $\alpha$-phenylallyl sulfone in $\mathrm{CH}_{3} \mathrm{CN}$ at $90{ }^{0} \mathrm{C}$ is rather slow $\left(\mathrm{k}=5.14 \times 10^{-5} \mathrm{sec}^{-1}\right)^{1 \mathrm{a}}$, the rate of rearrangement of cinnamyl triflinate in $\mathrm{CH}_{3} \mathrm{CN}$ is much faster (at $21^{0} \mathrm{C} \mathrm{k}=9 \times 10^{-5} \mathrm{sec}^{-1}$ ). Moreover, rearrangement of this triflinate at the same temperature in less polar solvent $\mathrm{CHCl}_{3}$ is slower than in $\mathrm{CH}_{3} \mathrm{CN}$ by a factor of $30\left(\mathrm{k}=3 \times 10^{-6}\right.$ $\sec ^{-1}$ ). Considering the decreased nucleophilicity of the sulfur atom in the cinnamyl triflinate, this dramatic rate enhancement is inconsistent with a concerted [2,3]-sigmatropic rearrangement. One should add that allylic triflone $\mathbf{8}$ undergoes an unusually facile isomerization to vinylic triflone $\mathbf{9}$. This reaction is significant since vinyl sulfones have become widely accepted as useful intermediates in organic synthesis. ${ }^{10}$

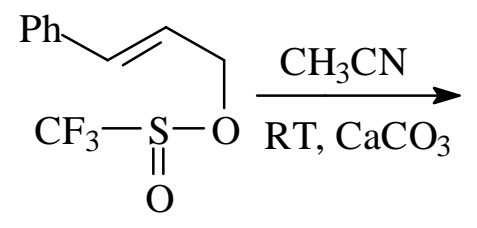

7a<smiles>C/C=C\C(c1ccccc1)S(=O)(=O)C(F)(F)F</smiles>

8<smiles>C/C=C(/c1ccccc1)S(=O)(=O)C(F)(F)F</smiles>

9<smiles>O=S(=O)(C/C=C/c1ccccc1)C(F)(F)F</smiles>

10

Next, we decided to test the reactivity of this ester under solvolytic conditions. Interestingly, the reaction of cinnamyl triflinate in dry ethanol in the presence of two equivalents of 2,6lutidine was spontaneous and a mixture of five products was obtained (eq. 12). Two main products (87\%) were obtained in the ratio of $1: 1$ and were identified as ethers 11 and 12. Three minor products were triflones $\mathbf{8 ,} \mathbf{9}$ and $\mathbf{1 0}(13 \%)$.

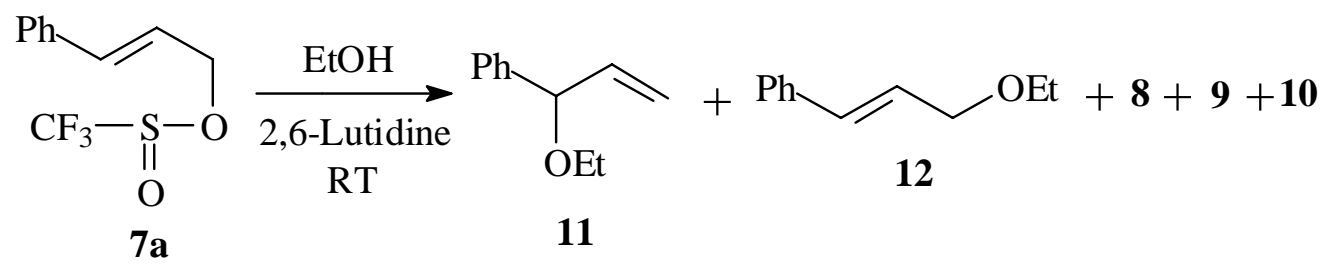

We believe that the evidence presented above is consistent with an ionization mechanism for both rearrangement and solvolysis reactions, resulting from the powerful leaving-group ability of the $\mathrm{CF}_{3} \mathrm{SO}_{2}{ }^{-}$anion, similar to the tosylate anion. ${ }^{4 \mathrm{~b}}$ For a better understanding of the reactivity of allylic triflinates we decided to investigate the reactivity of another derivative, $\alpha$-methylallyl triflinate $\mathbf{7 b}$. Surprisingly, and in contrast to cinnamyl triflinate, this ester underwent rearrangement to crotyl triflone $\mathbf{1 3}$ even under solvolytic conditions (eq. 13). In view of the mentioned above results, which were consistent with the reactivity of $\alpha$-methylallyl 2,6- 
dimethylbenzenesulfinate $^{1 \mathrm{a}}$ we suggest that the rearrangement of the last ester occurs by a concerted [2,3]-sigmatropic mechanism. The reason for the observed change in the mechanism may be the lower stability of the $\alpha$-methylallyl cation as compared to the cinnamyl one.

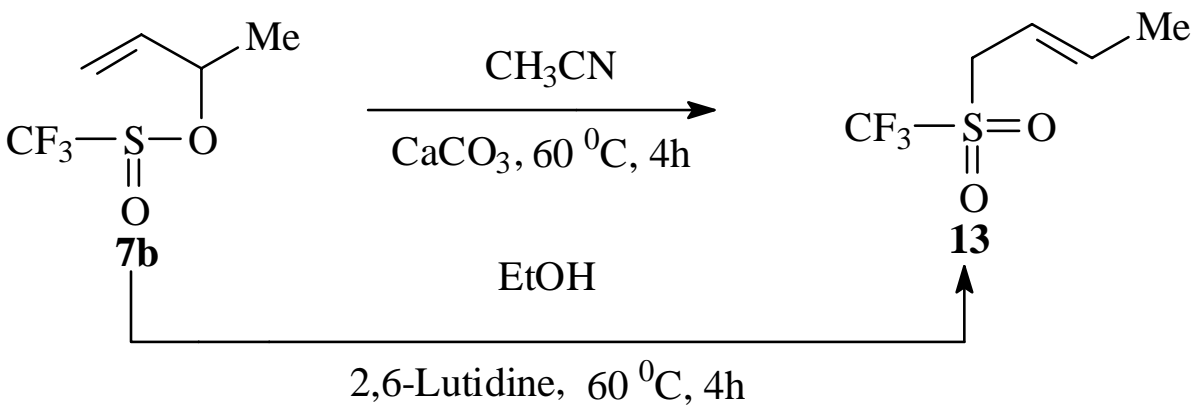

Next, we prepared and examined the reactivity of $\alpha, \alpha$-dimethylallyl triflinate 7c. Consistent with the higher stability of the corresponding carbocation, this ester rearranged spontaneously to a mixture of both $\gamma, \gamma$ - and $\alpha, \alpha$-dimethylallyl triflones 14 and 15 in the ratio of 3.3:1 respectively during preparation (overall yield is 60\%) (eq. 14).

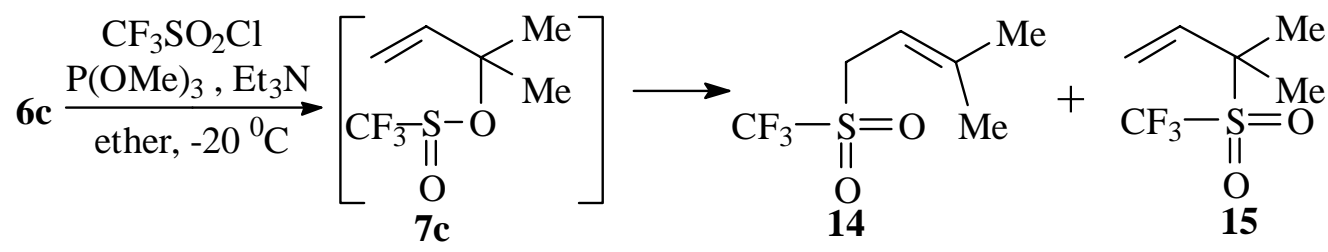

In conclusion, and in the light of the evidences presented above, it is suggested that the mechanism of the rearrangement of allylic triflinates to allylic triflones is strongly dependent on substitution. Thus, cinnamyl and $\alpha, \alpha$-dimethylallyl triflinates undergo both rearrangement and solvolysis reactions by an ionic mechanism. In contrast, $\alpha$-methylallyl triflinate undergoes rearrangement to crotyl triflones by a concerted [2,3]-sigmatropic mechanism even under solvolytic conditions. Although initiated by a mechanistic interest, the present work presents a route to highly active and synthetically useful allylic and allenic sulfones.

\section{Experimental Section}

General procedure for preparation of propargylic triflinates 2a-d and allylic triflinates 7a-c (triflinates 2d and 7c have not been isolated due to their rearrangement to the corresponding triflones 3d and a mixture of $\mathbf{1 4}$ and $\mathbf{1 5}$ respectively).

To a cooled $\left(-20{ }^{\circ} \mathrm{C}\right)$ solution of the appropriate alcohol $(3 \mathrm{mmol})$ and trifluoromethanesulfonyl chloride (3.75 mmol) in $10 \mathrm{ml}$ of dry ether, under a nitrogen atmosphere, were added simultaneously with stirring triethylamine $(3.75 \mathrm{mmol})$ and trimethyl phosphite $(3.75 \mathrm{mmol})$. After further stirring for two hours at this temperature and another $20 \mathrm{~min}$. at room temperature the reaction mixture was washed consecutively with water, $3 \%$ aqueous $\mathrm{HCl}, 5 \%$ aqueous 
$\mathrm{NaHCO}_{3}$, and water again. After drying over anhydrous $\mathrm{MgSO}_{4}$ and removal of the solvent the product was obtained as a viscous liquid. Due to high volatility of some products, the solvent was removed at $0{ }^{0} \mathrm{C}$.

a-Methylpropargyl triflinate (2a). A mixture of two diastereoisomers in the ratio of $1: 1.4$ (yield 70\%). ${ }^{1} \mathrm{H}$ NMR (300 MHz, $\mathrm{CDCl}_{3}$ ): $\delta 5.22$ (minor) and 5.20 (major) (qdq, $J=6.6,2.2,0.5$ $\mathrm{Hz}, 1 \mathrm{H}$ each), 2.76 (major) and 2.78 (minor) (d, $J=2.2 \mathrm{~Hz}, 1 \mathrm{H}$ each), 1.692 (major) and 1.689 (minor) (d, $J=6.6 \mathrm{~Hz}, 3 \mathrm{H}$ each), ${ }^{13} \mathrm{C} \mathrm{NMR}$ (75 MHz, $\mathrm{CDCl}_{3}$ ): $\delta 122.84$ (major) (q, $J=336.6 \mathrm{~Hz}$, $\mathbf{C F}_{3}$ ) and 122.75 (minor) (q, $J=335.1 \mathrm{~Hz}, \mathbf{C F}_{3}$ ), 79.59 (minor) and 79.53 (major) ( $\equiv \mathbf{C}-$ each), 78.14 (minor) and 77.97 (minor) (HC $\equiv$ each), 67.32 (major) and 67.22 (minor) (-CH-O each), 23.33 (major) and 22.66 (minor) $\left(-\mathrm{CH}_{3}\right.$ each), ${ }^{19} \mathrm{~F}$ NMR (200 $\left.\mathrm{MHz}, \mathrm{CDCl}_{3}\right): \delta-80.12$ (minor) and -80.62 (major) (s, $\mathrm{CF}_{3}$ each), IR (neat): 733, 908, 1130, 1205, 1380, $2255 \mathrm{~cm}^{-1}$, MS

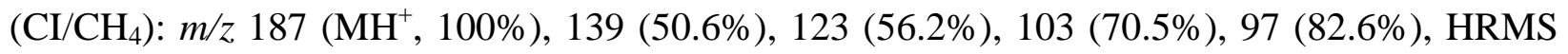
(elemental composition) : calc. $\left(\mathrm{C}_{5} \mathrm{H}_{6} \mathrm{O}_{2} \mathrm{~F}_{3} \mathrm{~S}\right)$ 187.004; found 187.006.

$\alpha, \alpha$-Dimethylpropargyl triflinate (2b). Yield 78\%. ${ }^{1} \mathrm{H}$ NMR (300 $\left.\mathrm{MHz}, \mathrm{CDCl}_{3}\right): \delta 2.90$ (s, 1H), 1.79 (s, 3H), 1.71 (s, 3H), ${ }^{13} \mathrm{C} \mathrm{NMR} \mathrm{(75} \mathrm{MHz,} \mathrm{CDCl}_{3}$ ): $\delta 122.9$ (q, $J=334.3 \mathrm{~Hz}, \mathrm{CF}_{3}$ ), $82.21(\equiv \mathbf{C}-)$, $78.79(-\mathbf{C}-\mathrm{O}), 78.38(\mathbf{C H} \equiv), 30.63(-\mathbf{C}-), 30.48\left(-\mathbf{C H}_{3}\right),{ }^{19} \mathrm{~F}$ NMR $(200 \mathrm{MHz}$, $\left.\mathrm{CDCl}_{3}\right): \delta-80.96$ (s, $\mathrm{CF}_{3}$ ), IR (neat): 789, 852, 1127, 1202, 1372, $2358 \mathrm{~cm}^{-1}, \mathrm{MS}\left(\mathrm{CI} / \mathrm{CH}_{4}\right): \mathrm{m} / \mathrm{z}$ $201\left(\mathrm{MH}^{+}, 100 \%\right), 149$ (64.1\%), 125 (61.2\%), 124 (66.5\%), HRMS (elemental composition): calc. $\left(\mathrm{C}_{6} \mathrm{H}_{8} \mathrm{O}_{2} \mathrm{~F}_{3} \mathrm{~S}\right)$ 201.019; found 201.021 .

$\alpha$-Ethyl- $\alpha$-methylpropargyl triflinate (2c). A mixture of two diastereoisomers in the ratio of 1:1 (yield 69\%). ${ }^{1} \mathrm{H}$ NMR (300 $\mathrm{MHz}, \mathrm{CDCl}_{3}$ ): $\delta 2.95$ and 2.94 (s, $1 \mathrm{H}$ each), 1.92 (AB system, $2 \mathrm{H}$ for both isomers), 1.76 and 1.66 (s, 3H each), 1.11 and 1.07 (t, $J=7.2 \mathrm{~Hz}, 3 \mathrm{H}$ each), ${ }^{13} \mathrm{C}$ NMR (75 MHz, $\mathrm{CDCl}_{3}$ ): $\delta 122.995$ and 123.005 (q, $J=334.3 \mathrm{~Hz}, \mathbf{C F}_{3}$ each), 82.76 ( $=\mathbf{C}-$ for both isomers), 79.82 and 79.75 ( $\mathbf{C H} \equiv$ each), 77.26 ( $-\mathbf{C}-\mathrm{O}$ for both isomers), 33.89 and 35.83 ( $-\mathrm{CH}_{2}-$ each), 28.89 and $28.32\left(-\mathrm{CH}_{3}\right.$ each), 8.58 and $8.38\left(-\mathrm{CH}_{2}-\mathrm{CH}_{3}\right.$ each), ${ }^{19} \mathrm{~F}$ NMR (200 $\mathrm{MHz}, \mathrm{CDCl}_{3}$ ): $\delta-81.00$ and -80.60 (s, $\mathrm{CF}_{3}$ each), IR (neat): 734, 868, 909, 1130, 1201, 1212, 1377, $2264 \mathrm{~cm}^{-1}$, MS (CI/I-Bu): $\mathrm{m} / \mathrm{z} 215\left(\mathrm{MH}^{+}, 22.0 \%\right), 81\left(\mathrm{M}^{+}-\mathrm{SO}_{2} \mathrm{CF}_{3}, 100 \%\right)$, HRMS (elemental composition): calc. $\left(\mathrm{C}_{7} \mathrm{H}_{10} \mathrm{O}_{2} \mathrm{~F}_{3} \mathrm{~S}\right)$ 215.035; found 215.039.

trans-Cinnamyl triflinate (7a). Yield 78\%. ${ }^{1} \mathrm{H}$ NMR (300 MHz, $\left.\mathrm{CDCl}_{3}\right): \delta 7.37$ (m, 5H), 6.76 (d, $J=15.6 \mathrm{~Hz}, 1 \mathrm{H}), 6.28$ (dt, $J=15.6,6.8 \mathrm{~Hz}, 1 \mathrm{H})$, ABq system: 4.99 (dd, $J=12.0,6.8 \mathrm{~Hz}$ ), 4.80 (dd, $J=12.0,6.8 \mathrm{~Hz}$ ), ${ }^{13} \mathrm{C}$ NMR $\left(75 \mathrm{MHz}, \mathrm{CDCl}_{3}\right): \delta 137.38(\mathrm{Ph}-\mathrm{CH}=), 135.24,128.79$, 128.69, 126.88 (Ar), 125.03 (q, $\left.J=339.0 \mathrm{~Hz}, \mathbf{C F}_{3}\right), 120.96\left(=\mathbf{C H}-\mathrm{CH}_{2}\right), 69.31\left(-\mathrm{CH}_{2}-\right),{ }^{19} \mathrm{~F}$ NMR (200 MHz, $\mathrm{CDCl}_{3}$ ): $\delta-79.47\left(\mathrm{~s}, \mathrm{CF}_{3}\right.$ ), IR (neat): triflinate rearranged to triflone while taking its spectrum (see spectra of triflones), $\mathrm{MS}\left(\mathrm{CI} / \mathrm{NH}_{3}\right): \mathrm{m} / \mathrm{z} 267\left(\mathrm{MNH}_{4}{ }^{+}, 33.0 \%\right), 151$ (15.0\%), 132 (100\%), $117\left(\mathrm{M}^{+}-\mathrm{OS}(\mathrm{O}) \mathrm{CF}_{3}, 100 \%\right)$, HRMS (elemental composition): calc. $\left(\mathrm{C}_{10} \mathrm{H}_{10} \mathrm{O}_{2} \mathrm{~F}_{3} \mathrm{~S}\right)$ 251.035; found 251.037.

1-Methyl-2-propenyl triflinate (7b). A mixture of two diastereoisomers in the ratio of 1:1 (yield 60\%). ${ }^{1} \mathrm{H}$ NMR (300 $\mathrm{MHz}, \mathrm{CDCl}_{3}$ ): $\delta 5.95$ and 5.87 (ddd, $J=17.1,10.5,6.9 \mathrm{~Hz}, 1 \mathrm{H}$ each), 5.41 and 5.39 (dt, $J=17.1,1.0 \mathrm{~Hz}, 1 \mathrm{H}$ each), 5.34 (dt, $J=10.5,1.0 \mathrm{~Hz}, 1 \mathrm{H}$ for both 
isomers), 5.04 and 5.03 (quintet, $J=6.9 \mathrm{~Hz}, 1 \mathrm{H}$ each), 1.54 and 1.51 (d, $J=6.9 \mathrm{~Hz}, 3 \mathrm{H}$ each), ${ }^{13} \mathrm{C}$ NMR (50 MHz, $\mathrm{CDCl}_{3}$ ): $\delta 136.31$ and 136.26 (=CH- each), 122.90 and 122.84 (q, $J=335.8$ $\mathrm{Hz}, \mathbf{C F}_{3}$ each), 119.52 and $119.31\left(\mathrm{CH}_{2}=\right.$ each $), 80.71$ and $80.06\left(\mathbf{C H}-\mathrm{CH}_{3}\right.$ each $), 21.66$ and 21.49 ( $-\mathrm{CH}_{3}$ each), ${ }^{19} \mathrm{~F}$ NMR (200 $\left.\mathrm{MHz}, \mathrm{CDCl}_{3}\right): \delta-80.88$ and -80.90 (s, $\mathrm{CF}_{3}$ each), IR (neat): 738, 912, 1130, 1202, $1366 \mathrm{~cm}^{-1}$, MS (CI/I-Bu): m/z $189\left(\mathrm{MH}^{+}, 33.0 \%\right), 173$ (36.0\%), 145 (100\%), 143 (91.0\%), 86 (25.0\%), HRMS (elemental composition): calc. $\left(\mathrm{C}_{5} \mathrm{H}_{8} \mathrm{O}_{2} \mathrm{~F}_{3} \mathrm{~S}\right)$ 189.019; found 189.019 .

General procedure for rearrangement of propargylic triflinates 2a-d to allenic triflones 3ad and allylic triflinates 7a-c to allylic triflones 8-10, 13,15

The rearrangement reaction was carried out by heating a solution of the appropriate ester (1 eq.) with $\mathrm{CaCO}_{3}$ (2 eq.) in dry acetonitrile. Then the reaction mixture was extracted with ether and washed 5 times with water. After drying over anhydrous $\mathrm{MgSO}_{4}$ the solvent was evaporated under reduced pressure and the residue was purified by silica gel chromatography.

* Due to high volatility of the products it was difficult to calculate a correct yield. Therefore, the yield was estimated by NMR experiments carried out in deuterated solvents like $\mathrm{CDCl}_{3}$ or $\mathrm{CD}_{3} \mathrm{CN}$ in NMR tubes.

$\gamma$-Methylallenyl triflone (3a). Yield 76\% ${ }^{*}{ }^{1} \mathrm{H}$ NMR (300 MHz, $\left.\mathrm{CDCl}_{3}\right): \delta 6.15$ (2H, m), 1.93 $(3 \mathrm{H}, \mathrm{m})$ (spectrum of second order), ${ }^{13} \mathrm{C}$ NMR $\left(75 \mathrm{MHz}, \mathrm{CDCl}_{3}\right): \delta 213.49$ (=C=), 119.74 (q, $J=$ $\left.326.0 \mathrm{~Hz}, \mathrm{CF}_{3}\right), 97.29\left(=\mathbf{C H}-\mathrm{SO}_{2} \mathrm{CF}_{3}\right), 91.63\left(=\mathbf{C H}-\mathrm{CH}_{3}\right), 12.36\left(-\mathrm{CH}_{3}\right),{ }^{19} \mathrm{~F}$ NMR $(200 \mathrm{MHz}$, $\left.\mathrm{CDCl}_{3}\right): \delta-80.10$ (s, $\left.\mathrm{CF}_{3}\right)$, IR (neat): 1121, 1208, 1379, $1952 \mathrm{~cm}^{-1}, \mathrm{MS}\left(\mathrm{CI} / \mathrm{NH}_{3}\right): \mathrm{m} / \mathrm{z} 187$ ( $\left.\mathrm{MH}^{+}, 85.9 \%\right), 171$ (15.6\%), 155 (34.4\%), 139 (12.5\%), HRMS (elemental composition): calc. $\left(\mathrm{C}_{5} \mathrm{H}_{6} \mathrm{O}_{2} \mathrm{~F}_{3} \mathrm{~S}\right)$ 187.004; found 187.005.

$\gamma, \gamma$-Dimethylallenyl triflone (3b). Yield 100\% ${ }^{*}{ }^{1} \mathrm{H}$ NMR (300 MHz, $\left.\mathrm{CDCl}_{3}\right): \delta 6.01$ (septet, $J=$ $2.8 \mathrm{~Hz}, 1 \mathrm{H}), 1.94$ (d, $J=2.8 \mathrm{~Hz}, 6 \mathrm{H}),{ }^{13} \mathrm{C} \mathrm{NMR}\left(75 \mathrm{MHz}, \mathrm{CDCl}_{3}\right): \delta 211.69$ (=C=), 121.73 $\left(\mathrm{CH}_{3}-\mathrm{C}=\right), 119.79\left(\mathrm{q}, J=326.0 \mathrm{~Hz}, \mathrm{CF}_{3}\right), 89.87(=\mathrm{CH}-), 18.98\left(-\mathrm{CH}_{3}\right),{ }^{19} \mathrm{~F}$ NMR $(200 \mathrm{MHz}$, $\left.\mathrm{CDCl}_{3}\right): \delta-80.20\left(\mathrm{~s}, \mathrm{CF}_{3}\right)$, IR (neat): 1120, 1197, 1222, $2010 \mathrm{~cm}^{-1}, \mathrm{MS}\left(\mathrm{CI} / \mathrm{CH}_{4}\right): \mathrm{m} / \mathrm{z} 201\left(\mathrm{MH}^{+}\right.$, 27.1\%), 103 (66.5\%), HRMS (elemental composition): calc. $\left(\mathrm{C}_{6} \mathrm{H}_{8} \mathrm{O}_{2} \mathrm{~F}_{3} \mathrm{~S}\right)$ 201.020; found 201.021.

$\gamma$-Ethyl- $\gamma$-methylallenyl triflone (3c). Yield 100\% ${ }^{*}{ }^{1} \mathrm{H}$ NMR (300 MHz, $\mathrm{CDCl}_{3}$ ): $\delta 6.09$ (tqq, $J$ = 3.0, 2.6, $0.8 \mathrm{~Hz}, 1 \mathrm{H}$ ), 2.22 (qd, $J=7.3,3.0 \mathrm{~Hz}, 2 \mathrm{H}$ ), 1.93 (d, $J=2.6 \mathrm{~Hz}, 3 \mathrm{H}$ ), 1.10 (t, $J=7.3$ $\mathrm{Hz}, 3 \mathrm{H}),{ }^{13} \mathrm{C}$ NMR $\left(75 \mathrm{MHz}, \mathrm{CDCl}_{3}\right): \delta 211.36(=\mathbf{C}=), 119.84\left(\mathrm{q}, J=326.1 \mathrm{~Hz}, \mathrm{CF}_{3}\right), 116.60$ $\left(\mathrm{CH}_{3}-\mathbf{C}=\right), 91.58(=\mathbf{C H}-), 26.56\left(-\mathrm{CH}_{2}-\right), 17.61\left(-\mathrm{CH}_{3}\right), 11.42\left(-\mathrm{CH}_{2}-\mathrm{CH}_{3}\right),{ }^{19} \mathrm{~F}$ NMR (200 $\left.\mathrm{MHz}, \mathrm{CDCl}_{3}\right): \delta-80.06\left(\mathrm{~s}, \mathrm{CF}_{3}\right)$, IR (neat): 1120, 1200, 1220, 1376, $2272 \mathrm{~cm}^{-1}, \mathrm{MS}\left(\mathrm{CI}^{-} \mathrm{CH}_{4}\right)$ : m/z 215 ( $\left.\mathrm{MH}^{+}, 46.4 \%\right), 207$ (75.5\%), 149 (45.8\%), 117 (34.8\%), HRMS (elemental composition): calc. $\left(\mathrm{C}_{7} \mathrm{H}_{10} \mathrm{O}_{2} \mathrm{~F}_{3} \mathrm{~S}\right)$ 215.035; found 215.037.

$\gamma$-Methyl- $\gamma$-phenylallenyl triflone (3d). Yield $71 \% .{ }^{1} \mathrm{H}$ NMR (300 MHz, $\left.\mathrm{CDCl}_{3}\right): \delta 7.40(\mathrm{~m}$, $5 \mathrm{H}), 6.42(\mathrm{q}, J=2.8 \mathrm{~Hz}, 1 \mathrm{H}), 2.31(\mathrm{~d}, J=2.8 \mathrm{~Hz}, 3 \mathrm{H}),{ }^{13} \mathrm{C}$ NMR $\left(50 \mathrm{MHz}, \mathrm{CDCl}_{3}\right): \delta 214.70$ $(=\mathbf{C}=), 131.27,129.67,129.06,126.64$ (Ar), 119.78 (q, $\left.J=326.5 \mathrm{~Hz}, \mathrm{CF}_{3}\right), 113.18\left(\mathrm{CH}_{3}-\mathbf{C}=\right)$, $93.33(=\mathbf{C H}-), 16.21\left(-\mathrm{CH}_{3}\right),{ }^{19} \mathrm{~F}$ NMR $\left(200 \mathrm{MHz}, \mathrm{CDCl}_{3}\right): \delta-79.78\left(\mathrm{~s}, \mathrm{CF}_{3}\right)$, IR (neat): 1119 , 
1203, 1220, 1374, $2254 \mathrm{~cm}^{-1}$, MS (EI/HR): $\mathrm{m} / \mathrm{z} 262\left(\mathrm{MH}^{+}, 2.5 \%\right), 129\left(\mathrm{MH}^{+}-\mathrm{SO}_{2} \mathrm{CF}_{3}, 100 \%\right)$, 128 (33.1\%), HRMS (elemental composition): calc. $\left(\mathrm{C}_{11} \mathrm{H}_{9} \mathrm{O}_{2} \mathrm{~F}_{3} \mathrm{~S}\right) 262.027$; found 262.024 .

1-Phenyl-2-propenyl triflone (8). Yield 16\% ${ }^{*}$. This triflone has not been isolated structure determination wwas carried out from a crude mixture.

${ }^{1} \mathrm{H} \mathrm{NMR}\left(300 \mathrm{MHz}, \mathrm{CDCl}_{3}\right): \delta 7.40(\mathrm{~m}, 5 \mathrm{H}), 6.28$ (dt, $\left.J=17.0,9.3 \mathrm{~Hz}, 1 \mathrm{H}\right), 5.65$ (d, $J=9.3 \mathrm{~Hz}$, 1H), 5.59 (d, $J=17.0 \mathrm{~Hz}, 1 \mathrm{H}), 5.04$ (d, $J=9.3 \mathrm{~Hz}, 1 \mathrm{H})$.

1-Phenyl-1-propenyl triflone (9). Yield 38\% ${ }^{1}{ }^{\mathrm{H}} \mathrm{NMR}\left(300 \mathrm{MHz}, \mathrm{CDCl}_{3}\right): \delta 7.50$ (q, $J=7.0$ $\mathrm{Hz}, 1 \mathrm{H}), 7.39$ (m, 5H), 1.92 (d, $J=7.0 \mathrm{~Hz}, 3 \mathrm{H}),{ }^{13} \mathrm{C} \mathrm{NMR}\left(75 \mathrm{MHz}, \mathrm{CDCl}_{3}\right): \delta 150.14(=\mathbf{C H}-)$, 141.74 (Ph-C=), 136.71, 130.59, 129.89, 128.84 (Ar), 120.06 (q, $\left.J=327.4 \mathrm{~Hz}, \mathrm{CF}_{3}\right), 16.18$ $\left(-\mathrm{CH}_{3}\right),{ }^{19} \mathrm{~F}$ NMR $\left(200 \mathrm{MHz}, \mathrm{CDCl}_{3}\right): \delta-76.84\left(\mathrm{~s}, \mathrm{CF}_{3}\right)$, IR (neat): 1122, 1212, $1361 \mathrm{~cm}^{-1}$, MS (CI/CH $): m / z 251\left(\mathrm{MH}^{+}, 9.4 \%\right), 135$ (5.8\%), 118 (11.0\%), $117\left(\mathrm{M}^{+}-\mathrm{SO}_{2} \mathrm{CF}_{3}, 100 \%\right), \mathrm{HRMS}$ (elemental composition): calc. $\left(\mathrm{C}_{10} \mathrm{H}_{10} \mathrm{O}_{2} \mathrm{~F}_{3} \mathrm{~S}\right)$ 251.035; found 251.036.

trans-Cinnamyl triflone (10). Yield 46\% ${ }^{*}{ }^{1} \mathrm{H}$ NMR (300 $\left.\mathrm{MHz}, \mathrm{CDCl}_{3}\right): \delta 7.40(\mathrm{~m}, 5 \mathrm{H}), 6.82$ (dtt, $J=15.9,1.3,0.6 \mathrm{~Hz}, 1 \mathrm{H}$ ), 6.15 (dtq, $J=15.9,7.6,0.5 \mathrm{~Hz}, 1 \mathrm{H}$ ), 4.15 (ddq, $J=7.6,1.3,0.7$ $\mathrm{Hz}, 2 \mathrm{H}),{ }^{13} \mathrm{C}$ NMR (75 MHz, $\mathrm{CDCl}_{3}$ ): $\delta 141.68$ (Ph-CH=), 134.97, 129.21, 128.80, 126.93 (Ar), 119.66 (q, $\left.J=326.0 \mathrm{~Hz}, \mathrm{CF}_{3}\right), 110.15\left(=\mathrm{CH}-\mathrm{CH}_{2}\right), 54.44\left(-\mathrm{CH}_{2}-\right),{ }^{19} \mathrm{~F} \mathrm{NMR}(200 \mathrm{MHz}$, $\left.\mathrm{CDCl}_{3}\right): \delta-77.32$ (s, $\left.\mathrm{CF}_{3}\right)$, IR (neat): 1120, 1206, $1370 \mathrm{~cm}^{-1}, \mathrm{MS}\left(\mathrm{CI} / \mathrm{CH}_{4}\right): \mathrm{m} / \mathrm{z} 251\left(\mathrm{MH}^{+}\right.$, 2.3\%), 233 (8.1\%), $117\left(\mathrm{M}^{+}-\mathrm{SO}_{2} \mathrm{CF}_{3}, 100 \%\right)$, HRMS (elemental composition): calc. $\left(\mathrm{C}_{10} \mathrm{H}_{10} \mathrm{O}_{2} \mathrm{~F}_{3} \mathrm{~S}\right)$ 251.035; found 251.030.

trans-Crotyl triflone (13). Yield 100\%* . ${ }^{1} \mathrm{H} \mathrm{NMR}\left(300 \mathrm{MHz}, \mathrm{CDCl}_{3}\right): \delta 6.02$ (dqt, $J=15.2,6.6$, $1.4 \mathrm{~Hz}, 1 \mathrm{H}$ ), 5.49 (dtq, $J=15.2,7.4,1.8 \mathrm{~Hz}, 1 \mathrm{H}$ ), 3.92 (ddq, $J=7.4,1.4,1.1 \mathrm{~Hz}, 2 \mathrm{H}$ ), 1.83 (ddt, $J=6.6,1.8,1.1 \mathrm{~Hz}, 3 \mathrm{H}),{ }^{13} \mathrm{C} \mathrm{NMR}\left(75 \mathrm{MHz}, \mathrm{CDCl}_{3}\right): \delta 139.69\left(=\mathbf{C H}-\mathrm{CH}_{2}\right), 119.72(\mathrm{q}, J=$ $\left.324.0 \mathrm{~Hz}, \mathrm{CF}_{3}\right), 112.60\left(=\mathrm{CH}-\mathrm{CH}_{3}\right), 54.03\left(-\mathrm{CH}_{2}-\right), 18.33\left(-\mathrm{CH}_{3}\right),{ }^{19} \mathrm{~F} \mathrm{NMR}(200 \mathrm{MHz}$, $\left.\mathrm{CDCl}_{3}\right): \delta-77.64\left(\mathrm{~s}, \mathrm{CF}_{3}\right)$, IR (neat): 1122, 1208, $1367 \mathrm{~cm}^{-1}, \mathrm{MS}(\mathrm{CI} / \mathrm{I}-\mathrm{Bu}): \mathrm{m} / \mathrm{z} 189\left(\mathrm{MH}^{+}\right.$, 7.8\%), 173 (100\%), 145 (84.4\%) 1345 (80.4\%), 129 (31.2), 84 (28.1\%), HRMS (elemental composition): calc. $\left(\mathrm{C}_{5} \mathrm{H}_{8} \mathrm{O}_{2} \mathrm{~F}_{3} \mathrm{~S}\right)$ 189.020; found 189.017 .

$\gamma, \gamma$ - and $\alpha, \alpha$-Dimethylallyl triflones 14 and 15 were obtained in the ratio of 3.3:1 respectively during preparation of $\alpha$, $\alpha$-dimethylallyl triflinate (overall yield 60\%). These triflones have not been isolated due to high volatility and structure determinations were carried out from a crude mixture by 2D NMR techniques: COSY (H, H and $\mathrm{C}, \mathrm{H})$.

$\alpha, \alpha$-Dimethylallyl triflones (15). Yield $14 \%{ }^{*} .{ }^{1} \mathrm{H}$ NMR (300 $\left.\mathrm{MHz}, \mathrm{CDCl}_{3}\right): \delta 5.86$ (dd, $J=$ 18.0, 11.0 Hz, 1H), 5.14 (dd, $J=18.0,1.5 \mathrm{~Hz}, 1 \mathrm{H}$ ), 5.12 (dd, $J=11.0,1.5 \mathrm{~Hz}, 1 \mathrm{H}$ ), 1.30 (s, 6H), ${ }^{13} \mathrm{C} \mathrm{NMR}\left(75 \mathrm{MHz}, \mathrm{CDCl}_{3}\right): \delta 144.11(=\mathbf{C H}-), 113.39\left(=\mathrm{CH}_{2}\right), 75.09(-\mathbf{C}-), 25.9 \pm 0.2\left(-\mathrm{CH}_{3}\right.$ groups).

$\gamma, \gamma$-Dimethylallyl triflones (14). Yield 46\% ${ }^{*}{ }^{1} \mathrm{H}$ NMR (300 MHz, $\left.\mathrm{CDCl}_{3}\right): \delta 5.24$ (tseptet, $J=$ 8.0, $1.2 \mathrm{~Hz}, 1 \mathrm{H}), 3.98$ (d, $J=8.0 \mathrm{~Hz}, 2 \mathrm{H}), 1.87$ (s, 3H), 1.78 (s, 3H), ${ }^{13} \mathrm{C} \mathrm{NMR}(75 \mathrm{MHz}$, $\left.\mathrm{CDCl}_{3}\right): \delta 146.74(=\mathbf{C}-), 105.41(=\mathbf{C H}-), 50.10\left(-\mathrm{CH}_{2}-\right), 17.95\left(-\mathrm{CH}_{3}\right), 25.9 \pm 0.2\left(-\mathrm{CH}_{3}\right),{ }^{19} \mathrm{~F}$ NMR (200 MHz, $\mathrm{CDCl}_{3}$ ): $\delta$-78.34 (s, $\mathrm{CF}_{3}$ ). For both isomers 15 and 14 IR (neat): 1121, 1205, $1365 \mathrm{~cm}^{-1}$, MS: $\mathrm{m} / \mathrm{z} 201.019\left(\mathrm{MH}^{+}, 100 \%\right)$, HRMS (elemental composition): calc. $\left(\mathrm{C}_{6} \mathrm{H}_{8} \mathrm{O}_{2} \mathrm{~F}_{3} \mathrm{~S}\right.$ ) 201.020; found 201.019. 


\section{General procedure for solvolysis of propargylic triflinates $\mathbf{2 b , c}$ and allylic triflinates $\mathbf{7 a , b}$.}

The solvolysis reaction was carried out by stirring of a solution of the appropriate ester (1 eq.) and 2,6-lutidine (2 eq.) in ethanol. The reaction mixture was extracted with ether and washed consecutively with water, $3 \%$ aqueous $\mathrm{HCl}, 5 \%$ aqueous $\mathrm{NaHCO}_{3}$, and water again. After drying over anhydrous $\mathrm{MgSO}_{4}$ and removal of the solvent the product was obtained as a viscous liquid.

* Due to high volatility of the products it was difficult to calculate a correct yield. Therefore, the yield was estimated by NMR experiments carried out in deuterated solvents like $\mathrm{CDCl}_{3}$ or $\mathrm{CD}_{3} \mathrm{CN}$ in NMR tubes.

$\beta$-Ethoxy- $\gamma, \gamma$-dimethylallyl triflone (5b). Yield 65\%. ${ }^{1} \mathrm{H}$ NMR (300 $\mathrm{MHz}, \mathrm{CDCl}_{3}$ ): $\delta 4.14$ (s, 2H), 3.74 (q, $J=7.0 \mathrm{~Hz}, 2 \mathrm{H}), 1.82$ (s, 3H), 1.77 (s, 3H), 1.28 (t, $J=7.0 \mathrm{~Hz}, 3 \mathrm{H}),{ }^{13} \mathrm{C}$ NMR (75 $\left.\mathrm{MHz} \mathrm{CDCl}_{3}\right): \delta 133.63(-\mathbf{C}=), 128.98(-\mathbf{C}=), 119.6\left(\mathrm{q}, J=327.5 \mathrm{~Hz}, \mathrm{CF}_{3}\right), 66.20\left(\mathrm{O}-\mathrm{CH}_{2}-\right)$, $50.61\left(-\mathrm{CH}_{2} \mathrm{SO}_{2} \mathrm{CF}_{3}\right), 19.44\left(-\mathrm{CH}_{3}\right), 18.05\left(-\mathrm{CH}_{3}\right), 15.06\left(-\mathrm{CH}_{2}-\mathrm{CH}_{3}\right),{ }^{19} \mathrm{~F}$ NMR (200 MHz, $\left.\mathrm{CDCl}_{3}\right): \delta-79.03\left(\mathrm{~s}, \mathrm{CF}_{3}\right)$, IR (neat): 1121, 1643, 1685, 1199, 1219, $1365 \mathrm{~cm}^{-1}$, MS (CI/CH$)_{4}$ : $\mathrm{m} / \mathrm{z} 247\left(\mathrm{MH}^{+}, 50.9 \%\right), 114\left(\mathrm{MH}^{+}-\mathrm{SO}_{2} \mathrm{CF}_{3}, 11.4 \%\right), 113(44.0 \%), 113\left(\mathrm{M}^{+}-\mathrm{SO}_{2} \mathrm{CF}_{3}, 100 \%\right)$, HRMS (elemental composition): calc. $\left(\mathrm{C}_{8} \mathrm{H}_{14} \mathrm{O}_{3} \mathrm{~F}_{3} \mathrm{~S}\right) 247.062$; found 247.060 .

$\beta$-Ethoxy- $\gamma$-ethyl- $\gamma$-methylallyl triflone (5c). Yield 58\%, as a mixture of two diastereoisomers $\mathrm{Z}$ and $\mathrm{E}$ in the ratio of 1:1.5 respectively. ${ }^{1} \mathrm{H} \mathrm{NMR}\left(600 \mathrm{MHz}, \mathrm{CDCl}_{3}\right): \delta 4.14$ (s, $2 \mathrm{H}$ for both isomers), 3.75 (E) and 3.72 (Z) (q, $J=7.2 \mathrm{~Hz}, 2 \mathrm{H}$ each), 2.25 (Z) and 2.08 (E) (q, $J=7.8 \mathrm{~Hz}, 2 \mathrm{H}$ each), 1.80 (E) and 1.74 (Z) (s, 3H each), 1.29 (E) and $1.28(\mathrm{Z})$ (t, $J=7.2 \mathrm{~Hz}, 3 \mathrm{H}$ each), 1.05 (E) and $1.02(\mathrm{Z})\left(\mathrm{t}, \mathrm{J}=7.8 \mathrm{~Hz}, 3 \mathrm{H}\right.$ each), ${ }^{13} \mathrm{C} \mathrm{NMR}\left(50 \mathrm{MHz}, \mathrm{CDCl}_{3}\right): \delta 134.42(\mathrm{Z})$ and $134.35(\mathrm{E})$ $\left(-\mathbf{C}=\right.$ each), $133.54(\mathrm{Z})$ and $133.45(\mathrm{E})\left(-\mathrm{C}=\right.$ each), $119.79\left(\mathrm{q}, J=328.3 \mathrm{~Hz}, \mathrm{CF}_{3}\right.$ each), 66.59 (Z) and 66.32 (E) (O- $\mathrm{CH}_{2}-$ each), $50.83(\mathrm{Z})$ and 50.60 (E) $\left(-\mathrm{CH}_{2} \mathrm{SO}_{2} \mathrm{CF}_{3}\right.$ each), 26.51 (E) and $24.77(\mathrm{Z})\left(\mathrm{O}-\mathrm{CH}_{2}-\right.$ each), $16.83(\mathrm{Z})$ and 15.23 (E) $\left(-\mathrm{CH}_{3}\right.$ each), 12.47 (E) and $12.33(\mathrm{Z})$ $\left(-\mathrm{CH}_{2}-\mathrm{CH}_{3}\right.$ each), ${ }^{19} \mathrm{~F}$ NMR (200 MHz, $\left.\mathrm{CDCl}_{3}\right): \delta-79.11(\mathrm{Z})$ and $-79.03(\mathrm{E})\left(\mathrm{s}, \mathrm{CF}_{3}\right.$ each), IR (neat): 1038, 1121, 1220, 1221, $1366 \mathrm{~cm}^{-1}, \mathrm{MS}\left(\mathrm{CI} / \mathrm{CH}_{4}\right): \mathrm{m} / \mathrm{z} 261\left(\mathrm{MH}^{+}, 27.8 \%\right), 127\left(\mathrm{M}^{+}\right.$$\left.\mathrm{SO}_{2} \mathrm{CF}_{3}, 100 \%\right), 127$ (89.5\%), HRMS (elemental composition): calc. $\left(\mathrm{C}_{9} \mathrm{H}_{16} \mathrm{O}_{3} \mathrm{~F}_{3} \mathrm{~S}\right) 261.077$; found 261.076.

$\beta$-Ethoxy- $\gamma$-methyl- $\gamma$-phenylallyl triflone (5d). Yield $81 \%$, as a mixture of two diastereoisomers $\mathrm{Z}$ and $\mathrm{E}$ in the ratio of $1.0: 1.1$ respectively. Was obtained according to the same procedure using $\gamma$-methyl- $\gamma$-phenylallenyl triflone $3 \mathbf{d}$ instead the appropriate triflinate. ${ }^{1} \mathrm{H}$ NMR (300 MHz, $\mathrm{CDCl}_{3}$ ): $\delta 7.32$ (m, 5H for both isomers), 4.28 (E) and 4.06 (Z) (2H each), $3.93(\mathrm{Z})$ and 3.47(E) (q, $J=7.0 \mathrm{~Hz}, 2 \mathrm{H}$ each), $2.12(\mathrm{Z})$ and $2.10(\mathrm{E})$ (s, 3H each), $1.38(\mathrm{Z})$ and $1.00(\mathrm{E})\left(\mathrm{t}, J=7.0 \mathrm{~Hz}, 2 \mathrm{H}\right.$ each), $\left.{ }^{13} \mathrm{C} \mathrm{NMR} \mathrm{(75} \mathrm{MHz,} \mathrm{CDCl}_{3}\right): \delta 139.94(\mathrm{Z})$ and $139.48(\mathrm{E})$ $\left(\mathrm{O}-\mathrm{C}=\right.$ each), $136.87(\mathrm{Z})$ and $136.63(\mathrm{E})\left(=\mathrm{C}(\mathrm{Ph})\left(\mathrm{CH}_{3}\right)\right.$ each), 133.70, 128.75, 128.16, 128.02, 127.84, 127.42 (Ar for both isomers), $119.71(\mathrm{Z})$ and $119.44(\mathrm{E})\left(\mathrm{q}, J=328.0 \mathrm{~Hz}, \mathrm{CF}_{3}\right.$ each), $67.50(\mathrm{E})$ and $66.37(\mathrm{Z})\left(-\mathrm{CH}_{2}-\mathrm{O}\right.$ each), $53.04(\mathrm{E})$ and $51.16(\mathrm{Z})\left(-\mathrm{CH}_{2}-\mathrm{SO}_{2} \mathrm{CF}_{3}\right.$ each), 20.17 (Z) and $19.04(\mathrm{E})\left(-\mathrm{CH}_{3}\right), 15.17(\mathrm{Z})$ and $15.14(\mathrm{E})\left(\mathrm{CH}_{2}-\mathrm{CH}_{3}\right.$ each), ${ }^{19} \mathrm{~F} \mathrm{NMR}(200 \mathrm{MHz}$, $\mathrm{CDCl}_{3}$ ): $\delta-78.98$ (E) and $-79.44(\mathrm{Z})$ (s, $\mathrm{CF}_{3}$ each), IR (neat): 1026, 1121, 1203, 1222, $1368 \mathrm{~cm}^{-1}$, MS (CI/CH $): m / z 308\left(\mathrm{M}^{+}, 9.4 \%\right), 293$ (1.4\%), 257 (10.3\%), $175\left(\mathrm{M}^{+}-\mathrm{SO}_{2} \mathrm{CF}_{3}, 100 \%\right), 147$ 
(26.5\%), 129 (23.2\%), HRMS (elemental composition): calc. $\left(\mathrm{C}_{13} \mathrm{H}_{15} \mathrm{O}_{3} \mathrm{~F}_{3} \mathrm{~S}\right)$ 308.069; found 308.072 .

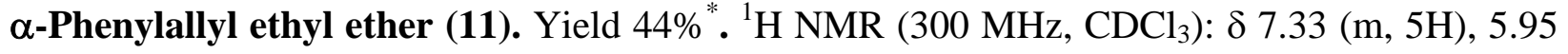
(ddd, $J=17.0,10.5,6.5 \mathrm{~Hz}, 1 \mathrm{H}$ ), 5.25 (dt, $J=17.0,1.5 \mathrm{~Hz}, 1 \mathrm{H}$ ), 5.18 (dt, $J=10.5,1.5 \mathrm{~Hz}, 1 \mathrm{H}$ ), 3.48 (AB system, 2H), $\left.1.23(\mathrm{t}, J=7.0 \mathrm{~Hz}, 1 \mathrm{H}),{ }^{13} \mathrm{C} \mathrm{NMR} \mathrm{(50} \mathrm{MHz,} \mathrm{CDCl}_{3}\right): \delta 139.30(=\mathbf{C H}-)$, 141.43, 128.41, 127.52, 126.83 (Ar), $115.92\left(=\mathrm{CH}_{2}\right), 82.90(-\mathbf{C H}-\mathrm{O}), 63.97\left(-\mathrm{CH}_{2}-\right), 15.29$

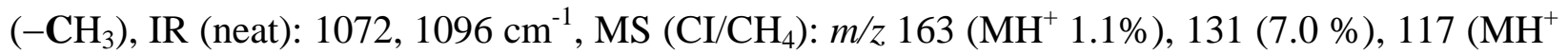
- EtOH, 100\%), HRMS (elemental composition): calc. $\left(\mathrm{C}_{11} \mathrm{H}_{15} \mathrm{O}\right) 163.112$; found 163.113. trans-Cinnamyl ethyl ether (12). Yield 44\% . ${ }^{1} \mathrm{H}$ NMR (300 MHz, $\left.\mathrm{CDCl}_{3}\right): \delta 7.32(\mathrm{~m}, 5 \mathrm{H})$, 6.61 (dt, $J=15.9,1.3 \mathrm{~Hz}, 1 \mathrm{H}), 6.30$ (dt, $J=15.9,5.9 \mathrm{~Hz}, 1 \mathrm{H}), 4.14$ (dd, $J=5.9,1.3 \mathrm{~Hz}, 2 \mathrm{H}$ ), $3.55(\mathrm{q}, J=7.0 \mathrm{~Hz}, 2 \mathrm{H}), 1.25(\mathrm{t}, J=7.0 \mathrm{~Hz}, 3 \mathrm{H}),{ }^{13} \mathrm{C} \mathrm{NMR}\left(50 \mathrm{MHz}, \mathrm{CDCl}_{3}\right): \delta 132.20$ ( $\mathrm{Ph}-\mathbf{C H}=$ ), 131.29, 128.55, 127.62, 126.51 (Ar), 126.51 (=CH-), $71.23\left(\mathrm{CH}-\mathrm{CH}_{2}-\mathrm{O}\right), 65.73$ $\left(-\mathrm{CH}_{2}-\mathrm{CH}_{3}\right), 15.25\left(-\mathrm{CH}_{3}\right)$, IR (neat): $1100 \mathrm{~cm}^{-1}$, MS $\left(\mathrm{CI} / \mathrm{CH}_{4}\right): \mathrm{m} / \mathrm{z} 179\left(\mathrm{MH}^{+} \mathrm{CH}_{4}, 29.0 \%\right)$, 177 (19.1\%), $163\left(\mathrm{MH}^{+}, 5.0 \%\right), 133\left(\mathrm{MH}^{+} \mathrm{CH}_{4}-\mathrm{EtOH}, 74.3 \%\right), 133$ (57.0\%), 131 (20.75\%), $117\left(\mathrm{MH}^{+}\right.$- EtOH, 30.1\%), 105 (100\%), 91 (32.4\%), 84 (27.5\%), HRMS (elemental composition): calc. $\left(\mathrm{C}_{11} \mathrm{H}_{14} \mathrm{O}\right)$ 162.104; found 162.106 .

Supporting Information Available: Full spectroscopic characterization data $\left({ }^{1} \mathrm{H}\right.$ NMR, ${ }^{13} \mathrm{C}$ NMR and HRMS) for all new compounds.

\section{Acknowledgements}

This research was supported by The Israel Science Foundation (grant No 563/98-1).

\section{References}

1. (a) Braverman, S. Ph. D. Thesis, University of Alberta, Edmonton, Canada, 1963. (b) Braverman, S.; Stabinsky, Y. J. Chem. Soc., Chem. Comm. 1967, 270. (c) Braverman, S.; Stabinsky, Y. Isr. J. Chem. 1967, 5, 125. (d) Braverman, S.; Mechoulam, H. Isr. J. Chem. 1967, 5, 71. (e) Tetrahedron 1974, 30, 3883.

2. (a) Braverman, S. In Chemistry of Sulfones and Sulfoxides; Patai, S.; Rappoport, Z.; Stirling, C. J. M. Eds.; Wiley: New York, 1988; Ch. 13. (b) Braverman, S.; ibid. Ch. 14. (c) Braverman, S. In The Chemistry of Sulfinic Acids, Esters and their Derivatives; Patai, S. Ed.; Wiley: New York, 1990; Ch. 11. (d) Braverman, S. In The Chemistry of Sulfenic Acids and their Derivatives; Patai, S. Ed.; Wiley: New York, 1990; Ch. 8.

3. Hassner, A.; Stumer, C. Organic Syntheses Based on Name Reactions and Unnamed Reactions; Pergamon Press: Oxford, 1994; p 266. 
4. (a) Braverman, S.; Duar, Y. Tetrahedron 1990, 46, 2975. (b) Braverman, S.; Manor, H. Phosphorus, Sulfur and Silicon 1990, 53, 357. (c) Braverman, S.; Steiner, S. Isr. J. Chem. 1967, 5, 267. (d) Harzdorf, C.; Meussdoerffer, J.-N.; Niederfprüm. H.; Wechsberg, M. Liebigs Ann. 1973, 33.

5. Nicolaou, K. C.; Skokotas, F.; Maligres, P.; Zuccarello, G.; Schweiger, E. S.; Toshima, K.; Wenderborn, S. Angew. Chem. Int. Ed. Engl. 1989, 28, 1271.

6. Klunder, J. M.; Sharpless, K. B. J. Org. Chem. 1987, 52, 2598.

7. (a) Pechenick, T. M. Sc. Thesis, Bar-Ilan University, 1998. (b) Braverman, S.; Pechenick, T.; Zafrani, Y. Tetrahedron Lett. 2001, 42, 1391.

8. (a) Stirling, C. J. M. J. Chem. Soc. C 1964, 5863. (b) Denmark, S. E.; Harmata, M. A. J. Org. Chem. 1987, 52, 4031. (c) Review: Landor, S. R. In The Chemistry of Allenes; Landor, S. R. Ed.; Academic: New York, 1982; Vol. 2, pp 361-397.

9. Hendrickson, J. B.; Skipper, P. L. Tetrahedron 1976, 32, 1627.

10. Simpkins, N. S. Tetrahedron 1990, 46, 6951. 